\title{
UDRŽITELNOST DEMOGRAFICKÉHO RŮSTU A MÍSTNÍ AGENDA 21
}

\section{SUSTAINABILITY OF DEMOGRAPHIC GROWTH AND LOCAL} AGENDA 21

\author{
DOC. DR. Lubomír PÁNA, Ph.D. \\ Katedra společenských věd $\mid$ Department of Social Sciences \\ Vysoká škola evropských a regionálních studii, o.p.s. $\quad$ College of European and Regional Studies \\ $\triangle$ Żižkova 4/6, 37001 České Budějovice, Czech Republic \\ E-mail:pana@vsers.cz
}

\begin{abstract}
Anotace
Řešení populačního problému je do značné miry spojeno $s$ kvalitou vládnutí, s posilováním individuálni ekonomické svobody a podporováni demokratických institucí. V České republice se tento problém snaži ř rešit Mistni Agenda 21, která je programem OSN pro 21. století a ukazuje cestu k udržitelnému rozvoji na naši planetě. Agenda se zaměřuje na všechny sektory společnosti a ke zlepšeni by mělo docházet, interakci mezi demografickými trendy a faktory a udržitelným rozvojem.

\section{Klíčová slova}

demografický růst, Mistní Agenda 21

\section{Annotation}

The solution of the population problem is more or less connected with the quality of reigning, the reinforcement of individual economic freedom and the support of democratic institutions. In the Czech Republic this problem is solved with the Local Agenda 21 which is the programme for 21 st century and it shows the way to the sustainable development on Earth. This agenda focuses on all the sectors of the society, and the improvement should come with the interaction among the demographic trends and the factors and the sustainable development.
\end{abstract}

\section{Key words}

demographic growth, Local Agenda 21

JEL classification: J11

\section{Úvod}

Earth Summit, kterého se pod záštitou OSN zúčastnilo v Riu de Janeiro od 3. června do 14. června 1992172 světových vlád, stanovil základní problémy lidstva a jako jeden ze základních a prioritních problémů $\mathrm{k}$ řešení uvedl problém „přelidněni“. V současné době obývá zemi něco přes 7 miliard obyvatel, a když se podíváme na křivku růstu, je střední odhad pro rok 2040 okolo 9 miliard obyvatel (dř́vější předpovědi odhadovaly až rok 2050-2060), a proto se již dnes hovoří o katastrofických scénářích.

Kolik lidí žilo na Zemi v dobách dávno minulých, není přesně zjistitelné. Koschin (2005) uvádí, že na přelomu letopočtu počet obyvatel na Zemi činil asi 250 milionů lidí, v českých zemích tehdy žilo přibližně 350000 lidí. Až do 18. století byl nárůst počtu obyvatel velmi pozvolný. S rozvojem průmyslové výroby se začala rozrůstat města, která kromě pracovních př́ležitostí nabízela lepší hygienické podmínky a dostupnější zdravotnickou péči, čímž se snižovala úmrtnost. Změna životního způsobu nesla $\mathrm{v}$ sobě i změnu př́stupu rodiny $\mathrm{k}$ ekonomické úloze dětí, které na venkově byly 
vnímány jako ekonomický př́nos, jako další pracovní síla. Život ve městech byl jiný a z dětí se ve městech stávala ekonomická přítěž, důsledkem toho bylo i snižování počtu dětí v rodině.

Od doby před 200000 lety, kdy se na planetě Zemi objevil člověk, až do dob římského císaře Julia Caesara nechodilo po povrchu planety nikdy více jak 250 milionů lidí. O 1500 let později, když Kolumbus objevil v roce 1492 Nový svět, byl počet obyvatel na světě okolo 500 milionů. Na přelomu 18. a 19. století překročil počet obyvatel první miliardu, ve 20 . století se populační růst ještě více urychlil.

Za posledních zhruba 200 let narostlo množství lidí dokonce o pět miliard. Za posledních padesát let počet obyvatel narostl 2,5 krát (Koschin, 2005, Braniš, 2006, s. 207-220). V současné době tak žije na naší planetě přes 7 miliard lidí, tento počet byl dle odhadů dosažen v polovině roku 2012. Obrázek 1 demonstruje odhad dalšího vývoje, kde je zřejmý určitý pokles dynamičnosti populačního růstu v dalších letech.

\section{Obr. 1: Růst světové populace}

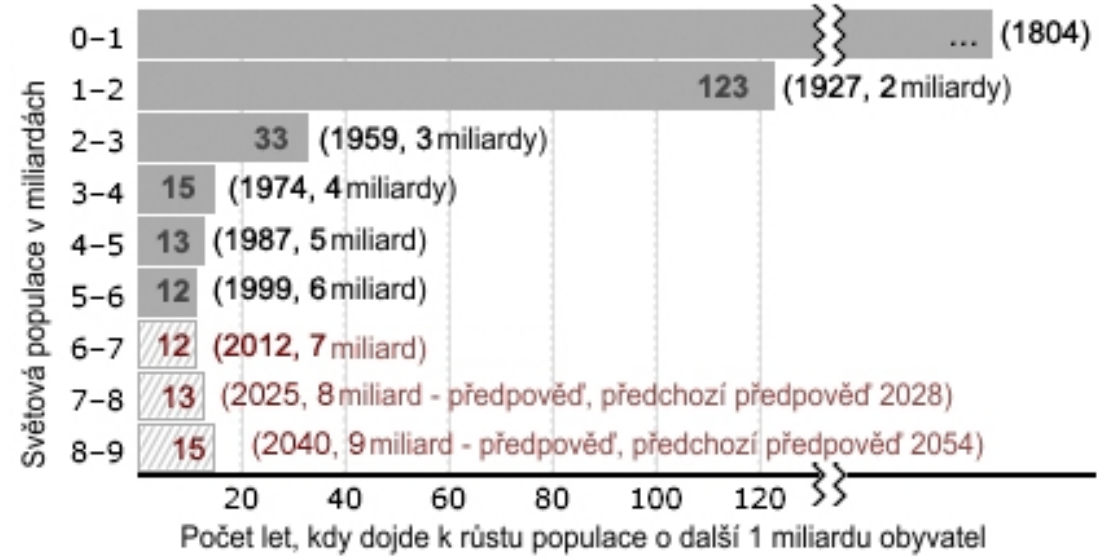

Zdroj: Wikipedie 2009, vlastní zpracování

\section{Cíl a metody}

Cílem př́spěvku je poukázat na vztah udržitelnosti demografického růstu a Místní Agendy 21. Je analyzován demografický růst obyvatel ve světě a poukázáno na některé problémy s tímto růstem související. Analýzou priorit Místní Agendy 21, ve vztahu k udržitelnému rozvoji, autor poukazuje na vztah mezi demografickými trendy a udržitelným rozvojem. Uvádí přehled všech trendů, které se touto problematikou zabývají. V závěru poukazuje na konkrétní stav řešení této problematiky v České republice.

\section{Výsledky a diskuse}

Demografický růst vyplývá ze změny životních podmínek a kvality života souvisejícím s rozvojem vědy, technologií, zdravotní péče, hygieny a dalších faktorů nejen ve vyspělých státech, ale i v rozvojových zemích. V důsledku toho klesá porodnost i úmrtnost - tj. faktory, které ovlivňují růst populace.

Paradoxní je rychlejší růst počtu obyvatel v méně vyspělých zemích, než v zemích s vyspělými ekonomikami. $Z$ této skutečnosti vyplývá, že $\mathrm{v}$ zemích vyspělejších populace stárne, zatímco $\mathrm{v}$ zemích méně vyspělých v důsledku rychlého demografického růstu populace mládne. „Zpráva EU o stárnutí populace - prognóza do roku 2060“ (Evropská komise, 2012) uvádí prognózu, podle níž bude mít Unie v roce 2060 celkově 517 milionů obyvatel, z čehož téměř jednu třetinu budou tvořit lidé starší 65 let. Oproti dnešku se celkový počet obyvatel do roku 2060 nijak dramaticky nezvýší (ze současných 502 milionů má vzrůst pouze na 517 milionů), populace však bude mnohem starší - 30 \% Evropanů bude patřit do věkové skupiny 65 let a více. I když prodloužení délky života můžeme považovat za 
velký úspěch, odvrácenou stranou mince jsou problémy, které dopadají na ekonomiky jednotlivých států a systémy sociálního zabezpečení. Jedná se především o snižování počtu ekonomicky aktivních obyvatel: podle odhadů se počet lidí ve věkové skupině od 15 do 64 let sníží z $67 \%$ na $56 \%$. Dnes na jednoho důchodce připadají 4 ekonomicky aktivní lidé, v budoucnosti se tento poměr sníží zhruba na 2 ekonomicky aktivní osoby. Předpokládá se, že tyto demografické změny budou mít velký dopad na veřejné finance států Unie. Vezmeme-li jako základ stávající př́stup, očekává se, že veřejné výdaje vynakládané výhradně v souvislosti se staršími občany (důchody, zdravotní a dlouhodobá péče) se v letech 2010 až 2060 zvýší o 4,1 procentních bodů HDP z $25 \%$ na $29 \%$ HDP. Jen samotné výdaje na důchody by se měly do roku 2060 zvýšit z $11,3 \%$ na téměř $13 \%$ HDP. Zpráva nicméně upozorňuje na velké rozdíly mezi jednotlivými státy, jež budou z velké části záviset na tom, jak který stát pokročí v provádění důchodových reforem.

Růst počtu obyvatel $\mathrm{v}$ oblastech méně vyspělých naopak předpokládá zvýšenou poptávku po pracovních místech, čímž se v těchto lokalitách snižují mzdy, roste nezaměstnanost a chudoba. S tím souvisí následně i problém ekonomické imigrace, kdy mnoho obyvatel opouští svou původní zemi s vidinou zbohatnutí a dosáhnutí lepší životní úrovně či vzdělání v ekonomicky vyspělejší zemi.

Demografický růst vyžaduje i zvyšování produkce potravin. S tímto faktem souvisí celá řada dalších problémů. Ruku v ruce s tím jde i otázka kvality potravin, více obyvatel planety dnes neumírá kvůli hladomoru ale kvůli tzv. malnutrici (nevyvážená kvalitní výživa). Dušek (2012, s. 146-154) též upozorňuje na elementární vztah základních zdrojů: energie-voda-potraviny.

Demografické trendy a faktory se staly globálním problémem životního prostředí a udržitelného rozvoje. Růst světové populace a výroby spojený s neudržitelnými vzory spotřeby stále vážněji zatěžuje potenciál naší planety pro podporování života. Populační politika by měla být zaměřena vazby mezi demografickými trendy a environmentálně šetrným využíáním zdrojů a vhodných technologií. Předpokládá se, že $\mathrm{v}$ roce 2025 počet obyvatel planety překročí 8 miliard. Je proto nezbytné zdůraznit vazby mezi dynamikou demografického růstu, technikou, kulturním chováním, př́rodními zdroji a systémy podporujícími život a na základě důkladné analýzy těchto faktorů vytvářet programy jak na úrovni národních států, tak i na úrovni mezinárodní. $\mathrm{V}$ těchto programech by měly být zahrnuty předpoklady udržitelnosti demografického růstu, které vychází z analýzy současného stavu a vyslovení priorit umožňujících hledat optimální řešení.

Priority udržitelného demografického vývoje se proto snaží nastínit Místní Agenda 21 (blíže viz Dušek, 2010 nebo Dušek, Pána, 2012), která je programem OSN pro 21. století a ukazuje cestu k udržitelnému rozvoji na naší planetě (Dušek, 2011). Dokument Agenda 21 byl přijat na summitu OSN v Rio de Janeiro v roce 1992. Jedná se o globální strategický a akční plán světového společenství, který stanovuje konkrétní kroky směrem k udržitelnému rozvoji. Právě tento dokument obsahuje vymezení toho, oč v místní Agendě 21 (MA21). Agenda 21 je souhrnný název asi 38 obecných okruhů (odpady, chudoba, ochrana vody, ochrana prŕrody). Tyto problémy souvisejí s kvalitou životního prostředí, ekologickou šetrností, sociální a zdravotní pohodou občanů zemí celého světa a samožrejmě i s demografickými změnami (viz také Krajšek, 1998).

Zaměříme-li se na současnou dynamiku demografického růstu a jeho (trvalou) udržitelnost, pak ve všech sektorech společnosti by mělo být dle autora tohoto př́spěvku zlepšeno porozumění interakcí mezi demografickými trendy a faktory a udržitelným rozvojem:

- věnovat větší pozornost při tvorbě obecné politiky a při sestavování plánů rozvoje zaměřených na řešení důsledků růstu počtu obyvatel zahrnutého do dynamiky populace,

- vytvářet a implementovat programy národní populační politiky, v souladu s národními environmentálními a rozvojovými plány pro udržitelný rozvoj za předpokladu jejich slučitelnosti se svobodou, důstojností a osobně vyznávanými hodnotami jednotlivců,

- holisticky přistupovat $\mathrm{k}$ populačním a environmentálním problémům při stanovování a implementaci cílů zahrnujících zmírňování chudoby, zajištování živobytí, dobré zdraví, kvalitu života, zlepšení postavení a příjmu žen a jejich př́stupu ke vzdělání, 
- analyzovat vztahy mezi demografickými trendy a faktory a změnou životního prostředí a mezi zhoršováním kvality životního prostředí a prvky demografické změny,

- identifikovat rozsah možných důsledků současných lidských činností zejména z hlediska dopadu demografických trendů a faktorů, využívání zdrojů, migračních toků, souvisejících $\mathrm{s}$ rostoucím počtem klimatických událostí a změnami životního prostředí, majících ničivé účinky na místní zdroje živobytí,

- zlepšovat postavení žen prostřednictvím lepšího přístupu ke vzdělání, informacím, zdravotní péči, ekonomické nezávislosti,

- mobilizovat potenciál žen $\mathrm{v}$ oblastech pracovních, právních, majetkových, umožnit jim rozhodovat velikosti rodiny, počtu dětí, při současném zachování jejich lidské důstojnosti,

- posilovat zdravotní péči o ženy v souladu s předpoklady udržení dobrého zdraví v oblasti reprodukční péče a zdravotní péče všem dětem a tím přispívat ke snižování rizik úmrtnosti a chorob dětí a matek,

- identifikovat zranitelné skupiny obyvatelstva (např. venkovští pracovníci nevlastnící půdu, etnické menšiny, uprchlíci, migranti, lidé bez domova, ženské hlavy domácností), jejichž změny v demografické struktuře mohou mít specifické dopady na udržitelný rozvoj,

- posoudit důsledky věkové struktury populace na poptávku po zdrojích a na problémy se závislostmi, pohybující se od výdajů na vzdělání pro mladé, po zdravotní péči a podporu pro staré lidi, a na tvorbu př́ijmů domácností,

- posoudit také národní kapacitu pro vyživování populace, z hlediska uspokojování lidských potřeb a udržitelného rozvoje, a věnovat zvláštní pozornost kritickým zdrojům, jako je voda a půda, a environmentálním faktorům, jako je zdraví ekosystémů a biodiverzita,

- zkoumat dopad národních demografických trendů a faktorů na tradiční živobytí domorodých skupin a místních komunit, včetně změn v tradičním využívání půdy a pozemků, způsobených vnitřními populačními tlaky, brány $\mathrm{v}$ úvahu potřeby zdrojů, produkování odpadů a zdraví ekosystému,

- vytvářeny plány zvládání různých typů migrace, které jsou následkem nebo přićínou narušení životního prostředí, se zvláštním ohledem na ženy a na zranitelné skupiny,

- pozornost věnována programům zvyšování gramotnosti obyvatelstva, zejména žen,

- zvýšit potenciál národních, regionálních a místních struktur (institucí) pro řešení problémů souvisejících s demografickými trendy a faktory a s udržitelným rozvojem,

- zvýšit potenciál relevantních orgánů, organizací a institucí OSN, mezinárodních a regionálních mezivládních orgánů, nevládních organizací a místních komunit, aby tyto instituce byly schopny pomáhat jednotlivým zemím,

- zlepšit porozumění sociokulturním a politickým faktorům, které mohou pozitivně ovlivnit přijatelnost vhodných nástrojů populační politiky.

\section{Závěr}

Jak významný problém představuje přelidnění je zrejmé z mnoha vědeckých studií. Joseph Tainter, americký antropolog a historik, ve své knize Kolapsy složitých společností (Tainter, 2009) uvádí jako hlavní prríčinu kolapsů lidských i ostatních společností právě vyčerpání a zánik zdrojů nezbytných pro život. Populačním problém se např́iklad zabývá i studie vojenského paktu NATO z roku 2011 „Populační růst - celosvětový problém 21. století“ (Fox, 2012). Řešení populačního problému je tedy do značné míry tedy spojeno s kvalitou vládnutí, tj. s posilováním individuální ekonomické svobody a podporováním demokratických institucí. Rovněž snižování břemene zadluženosti rozvojových zemí, liberalizacemezinárodního obchodu a poskytování finanční pomoci a př́stupu $\mathrm{k}$ technologiím podporujedosažení hospodářského pokroku a zmírňování chudoby, která s tímto fenoménem souvisí. Vlády většiny zemí světa se však tento problém nesnaží intenzivně řešit a země G20 ho zcela ignorují, ačkoliv odborníci dlouhodobě na tento problém poukazují. Právě Místní Agenda 21 se snaží tento problém řešit a zapadá do širšího celosvětového proudu snahy o kvalitní veřejnou správu, která je zahrnuta pod pojem „good governance“ (,řádná správa věcí veřejných“ či „,dobré vládnutíc). Jedině kvalitní správa věcí veřejných může vést $\mathrm{z}$ pohledu OSN $\mathrm{k}$ dlouhodobě udržitelnému rozvoji regionů. Postup měst, obcí a regionů je nyní v rámci kvalitní MA21 přehledně měřitelný kritérii MA21, která jsou od roku 2010 přizpůsobena pro všechny typy regionů. Zároveň lze komparací jednotlivých 
parametrů u zainteresovaných aktérů na všech úrovních jasně prokázat, zda a jak jsou naplňovány mezinárodní standardy MA21. Mezi nejaktivnější v oblasti MA21 patří v České republice Národní sít' zdravých měst (NSZM), která je v současné době tvořena skoro stovkou municipalit ČR, z nichž přibližně 40 patř́ mezi nejpokročilejší realizátory MA21 v ČR. Důvod je velmi prostý - hlavním nástrojem postupu Zdravého města, obce či regionu je právě metoda kvality ve veřejné správě místní Agenda 21.

Přestože naplňování kritérií MA21 může přinést i přímé finanční efekty například díky vyšší úspěšnosti v různých grantových schématech Evropské unie či národních grantech, hlavní cíl je úplně jiný... lépe a efektivněji strategicky řídit obec, město, mikroregion, kraj apod. To vše tak může napomoci vyšší kvalitě života občanů jednotlivých regionů. Co víc lze říci na závěr, snad jen to, že lze jen doufat, že se naplní Strategická vize rozvoje místní Agendy 21 v ČR do roku 2020, která uvádí... „Do roku 2020 dojde ke zvýšení počtu kvalitnich MA21 v ČR - obce a dalš́ subjekty aktivně usilují o zavedeni MA21 a politická reprezentace poskytuje procesům MA21 dostatečnou morálni a finanční podporu. Stále širší a kvalitnějš́ realizace MA21 v obcich a regionech České republice bude mit podpůrný vliv na dalši demokratický vývoj občanské společnosti a na transparentnost a efektivitu veřejné správy." Implementace principů agendy MA21 v jakémkoliv regionu je velmi pozitivní zjištění, jedná se však o velmi dlouhodobý proces, jehož skutečné výsledky se projeví až v následujících desetiletích.

\section{Literatura}

[1] BRANIŠ, M. Globální problémy životního prostředí. In Dlouhá, J., Dlouhý, J., Mezřický, V. (eds.) Globalizace a globálni problémy. Praha : UK, Centrum pro otázky životního prostředí, 2006. s. 207-220. ISBN 80-87076-01-X.

[2] DUŠEK, J. Faktory regionálního růstu a rozvoje (se zaměřením na spolupráci měst a obcí v Jihočeském kraji). 1. vydání. České Budějovice : Vysoká škola evropských a regionálních studií, o.p.s., 2010. 294 s. ISBN 978-80-86708-94-2.

[3] DUŠEK, J. Faktory regionálního růstu a rozvoje (se zaměřením na spolupráci měst a obcí ve Středočeském kraji). 1. vyd. České Budějovice: Vysoká škola evropských a regionálních studií, 2011. 100 s. ISBN 978-80-87472-13-2.

[4] DUŠEK, J. Komoditní krize ve světě. In Dušek, J., Pána, L., Svatoš, R. et al. Udržitelný rozvoj a funkce moderního evropského státu. 1. vyd. České Budějovice: Vysoká škola evropských a regionálních studií o. p. s., 2012. s. 146-154. ISBN 978-80-87472-20-0.

[5] DUŠEK, J., PÁNA, L. Zdravá města a Mistní Agenda 21. 1. vyd. České Budějovice: Vysoká škola evropských a regionálních studií, 2012. 146 s. ISBN 978-80-87472-07-1.

[6] FOX, T. Populačni růst - celosvětový problém 21. století [online]. NATO Review, 2012 [cit. 2013-01-11]. Dostupné z: <http://www.regionalscience.org/>.

[7] KOSCHIN, F. Demografie poprvé. Praha : Oeconomica, 2005. 122 s. ISBN 80-245-0859-1.

[8] KRAJŠEK, B. Úvod k místním Agendám 21 v České republice. Praha: Ministerstvo životního prostředí, 1998. $44 \mathrm{~s}$. ISBN 80-7212-052-2.

[9] Stárnouci Evropa? Skutečnost, na kterou je třeba se připravit [online]. Brusel : Evropská komise, 2012, 15.5.2012 [cit. 2013-04-30]. Dostupné z: $<$ http://ec.europa.eu/news/economy/120515_cs.htm>.

[10] TAINTER, J. A. Kolapsy složitých společností. Praha: Dokořán, 2009. 319 s. ISBN 978-80-7363248-9.

[11] World population growth [online]. Wikipedia, 2009, 6.3.2009 [cit. 2013-04-30]. Dostupné z: $<$ http://en.wikipedia.org/wiki/File:World_population_growth_-_time_between_each_billionperson_growth.jpg>, vlastní zpracování. 